\title{
Marxist Perspectives on the Global Enclosures of Social Reproduction
}

\author{
Friederike Beier
}

\section{Freie Universität Berlin, Germany, friederike.beier@fu-berlin.de}

\begin{abstract}
Women's unpaid care and domestic work is gaining relevance in policy-making as well as in academia. Feminist scholars and activists have lobbied successfully for the integration of unpaid care and domestic work into the Sustainable Development Goals (Goal 5.4) of the United Nations in the hope for greater recognition of women's contribution to the economy. Policy documents about social reproduction highlight women's disproportionate share of reproductive activities as an obstacle to women's economic empowerment and as a relic of 'traditional' gender roles. Social reproduction is thereby not understood as a merit in itself, but as an obstacle to women's participation in paid labour. Policy implications will enable certain empowerment effects for some women, but at the same time promote the increasing privatization and commodification of reproductive work across the globe. Rising inequalities between the Global North and South and between women along the categories of class and race will be one major result. To theoretically explain such contradictory effects of the recognition of social reproduction, I use the concept of 'enclosures' based on Marx' 'primitive accumulation'. Feminist scholars use the concept to explain how unpaid care and housework is commodified or de-commodified to integrate women into the paid labour force or to reduce the costs of social reproduction according to the needs of the economy. The sudden interest in unpaid care and domestic work e.g. in the Sustainable Development Goals can therefore be seen as process of double enclosure, which integrates women into the paid labour force, but also sets the grounds for the further commodification of domestic and care work. This paper aims to critically discuss the sudden interest in unpaid domestic and care work and its contradictory effects from a Marxist feminist perspective and reflects on feminist strategies and movements in global governance. After introducing Marxist perspectives on social reproduction, the question if and how feminist ideas and concepts have been appropriated, the effects and implications of global policies on social reproduction and global inequalities, as well as possible counter-strategies will be discussed.
\end{abstract}

Acknowledgement: I want to thank Karin, my mother, who did all the reproductive work during her Christmas holidays while I was working on this article. I also want to thank my dear friends Deborah Sielert, Moritz Altenried, Bernardo Bianchi, Frank Engster and Martin Fries for their useful and encouraging comments, as well as Sarah Hönig and Dominik Arncken for their linguistic and other support. Special thanks go to Tove Soiland, who not only provided useful comments, but also inspired the entire article with her work and seminars on feminist perspectives on the concept of Landnahme (enclosure).

Keywords: social reproduction, primitive accumulation, enclosure, unpaid work, housework, care, gender, global inequality, intersectionality, economic empowerment, United Nations, sustainable development goals, politics of appropriation, feminism, feminist strategies

\section{Introduction}

Women globally spend on average about three times as much time on unpaid care and domestic tasks as men (UN 2017b). After decades spent in a shadowy existence, unpaid care and domestic work are suddenly widely debated in the context of global 
governance and considered as the missing piece of the puzzle in understanding women's smaller participation in the paid labour force (OECD et al. 2014). International governmental organisations, like the Organisation for Economic Cooperation and Development (OECD), the European Union and the United Nations are even integrating the recognition of social reproduction into their social and development policies (EU 2016; OECD et al. 2014; UN 2015).

Does this sudden interest mark a final success after decades of interventions and lobbying by feminist networks and movements, like the 'wages for housework' movement in the 1970s (e.g. Cox and Federici 1975; Dalla Costa and James 1972) or more recently by transnational feminist movements in the context of global governance (Razavi 2007)? Or, to put it simply: Is the private finally political and, as such, recognised by the state(s)? Judging from a Marxist perspective, these new developments should warrant a more sceptical appraisal, especially because the new social policies link the recognition of reproductive work to women's economic empowerment, aka their exploitation in the paid labour force (EU 2016; OECD et al. 2014; UNDP 2016b).

In this article, I argue that these policies focusing on women's integration into paid labour can be elucidated as instruments of enclosures based on Marx's concept of primitive accumulation, which he introduced in Capital, Vol. I (Marx 1990/1867). Therein, he describes mechanisms of appropriation or enclosure of spheres (e.g. commons or unpaid work), which used to be external to the capital accumulation process and how the (continuous) reproduction of capitalism is based on such mechanisms (e.g. Brown 2009; De Angelis 2001; Glassman 2006; Hartsock 2006; Sanyal 2014). Feminist materialist critique has exposed that women's unpaid housework as an external sphere is itself not outside, but constitutive for capitalist accumulation and that non-regular work is the basis on which the formal economy is built. Processes of enclosure are therefore important to understand atypical and nontraditional forms of exploitation, especially in the Global South, which have been - to a large extent - neglected by Marxist scholarship (Bennholdt-Thomsen and Mies 2000; Mies 1986).

The renewed interest in unpaid care and domestic work in global governance and its probable impacts even leads to a process of double enclosure: First, the policies aim at including women into the modes of production through their so called 'economic empowerment', whereby unpaid work is appropriated in the process. Second, as a concomitant of women's incorporation into the global formal economy, the further commodification of social reproduction is induced.

The commodification of social reproduction means that formerly unpaid domestic tasks are transformed into paid work in and outside of private households. Paid care and domestic work will most likely still be carried out by women at most precarious conditions due to the labour intensity or "cost disease" (Baumol 2012) of the care sector and its limited capacity to increase productivity, besides cutting the costs of labour (Madörin 2011).

I will show that both processes of enclosure, women's integration into the paid workforce and the further commodification of care and domestic tasks, will further exacerbate inequality, especially between women along the categories of ethnicity/race and class. The double enclosure is ironically based on the appropriation of feminist theory and practice, which identified the economic role of social reproduction in the first place. To make my argument, I will first (section 2) elaborate on the United Nations Sustainable Development Goals (SDGs) and the new interest in social reproduction in global governance before I turn to (section 3 ) the concept of 
primitive accumulation and its de- and reconstructions by Marxist and feminist scholars. I will then (section 4) use the example of the SDGs and its Goal number 5.4, which entails the recognition of unpaid care and domestic work to illustrate how the feminist conceptualization of social reproduction is being appropriated through its formal recognition and why it can be theorised as a double form of enclosure. I will furthermore explore some likely effects on the sexual and international division of labour and its social and economic inequalities, before I conclude with possible feminist Marxist counter strategies (section 5).

The significance of social reproduction for gender relations is not new in feminist thinking and activism. It was made prominent by feminists in the 1970s through the international campaign 'wages for housework' (Cox and Federici 1975; Dalla Costa and James 1972). Feminist and materialist literature theorising social reproduction has furthermore emphasised the substantial meaning of unpaid care and housework for the reproduction of capital relations (e.g. Bakker and Gill 2003; Donath 2000; Federici 2012a; Mies 1986; Rai, Hoskyns and Thomas 2014). The function of social reproduction for capital accumulation, as well as the contradictory relation between the reproductive and productive spheres, are also central to feminist scholarship (e.g. Federici 2014; Fraser 2016; Hartsock 2006).

I build on this rich body of feminist literature in order to grasp the complex mechanisms in which global social policies relate to and expropriate women's unpaid work on a global scale. Broader definitions of reproduction include sexual reproduction as well as the reproduction of social structures and systems, in which education plays a major role (Althusser 2014). For the purpose of this article, I use social reproduction to describe unpaid work in the realm of the home, including care, domestic, voluntary and subsistence work, carried out for family members as well as the broader community (cf. Rai, Hoskyns and Thomas 2014).

\section{The Sustainable Development Goals and the Recognition of Social Reproduction in Global Governance}

The Agenda 2030 and the respective Sustainable Development Goals (SDGs) mark a major breakthrough compared to the preceding Millennium Development Goals (Kabeer 2015). Adopted by the General Assembly of the United Nations in October 2015, the 17 SDGs, 169 targets and 232 indicators are setting a strong framework for global politics and promise 'transforming our world' in the next 15 years. The universality of the Agenda is built on 'Global Partnership' and "global solidarity, focussed in particular on the needs of the poorest and most vulnerable [...]" (UN 2015).

Although the implementation process is viewed with scepticism due to insufficient financing ${ }^{1}$, the SDGs are acclaimed for their transformative potential and designated as a "new global governance approach" (Stevens and Kanie 2016). The "Leave Noone behind' Agenda was a direct consequence of the critique on the omission of social and economic inequalities in the 'Minor Development Goals' (Stuart and Woodroffe 2016). This new focus on vulnerable and marginalised groups supposedly follows an intersectional approach and includes the categories of sex, age, disability, race,

\footnotetext{
${ }^{1}$ The further financing and implementation strategies of the SDGs were operationalised by the donor states in the Addis Ababa Action Agenda 2015, in which specific goals and targets like "Social protection for all" (SDG 1.3) are marginalised and its financing left unclear. In contrast to the focus of the SDGs on global partnerships, important details are determined by donor countries alone without much civil society involvement (Stuart and Woodroffe 2016).
} 
ethnicity, religion, economic or other 'status' and thus links economic inequalities with 'group based' discrimination (SDG 10). The paradigmatic shift in policies was triggered by reflections about human capital and the realisation that growing inequalities have a negative effect on development and economic growth as promoted by European states and the OECD (Razavi 2007). Two studies were published shortly before the ratification of the SDGs: The International Monetary Fund (Ostry, Berg, and Tsangarides 2014) and the OECD (OECD and Cingano 2014) identified high levels of inequality within and between countries as a hindrance for economic growth. It is therefore no surprise that the Agenda 2030 is built on the creed of economic growth as a remedy for poverty and unemployment (UN 2015).

Feminist scholars regard the SDGs with "cautious optimism" (Kabeer 2015) and welcome the stand-alone-goal on gender equality (SDG 5), which aims to "achieve gender equality and empower all women and girls", as a huge success in comparison to the limited approach to gender equality of the MDGs (Esquivel 2016; Razavi 2016). The integration of unpaid care and housework into the SDGs is one example of successful lobbying of feminist networks in the hope for greater recognition of women's contribution to the economy (Razavi 2016; UN 2015; 2017a). Target 5.4 aims to "recognize and value unpaid care and domestic work through the provision of public services, infrastructure and the promotion of shared responsibility within the household and the family as nationally appropriate" (UN 2015). Despite a long history of feminist interventions, mainstream international political economy as well as economic and social policies ${ }^{2}$ have - apart from a few exceptions (e.g. Beijing Platform for Action) repeatedly failed to recognise the importance of social reproduction for achieving gender equality (Donath 2000; Elson 1998).

This new interest in unpaid care and domestic work should be considered in relation to the crisis or depletion of social reproduction due to demographic changes in the Global North and the rising participation of women in the formal workforce (Rai, Hoskyns and Thomas 2014; Winker 2015). Unpaid domestic and care work is interpreted as one of the main obstacles to women's economic empowerment by numerous policies and policy papers (e.g. Bibler and Zuckerman 2013; European Parliament 2017; EU 2016; OECD et al. 2014; UNDP 2016a; 2016b; Williams 2010). Even though this reduction of the situation of women to human capital ${ }^{3}$ was widely criticised (Esquivel 2016; Fraser 2016; Kabeer and Natali 2013), it was the major contribution of a feminist scholarship to identify and clarify the interdependence between paid and unpaid work in the first place (Antonopoulos 2009; Himmelweit 1995).

${ }^{2}$ The experience of feminist research on social protection policies in welfare states in the Global North shows that social policies are never gender neutral, but rather deeply entrenched in an androcentric logic. The motivation for women's protective legislation was, for instance, used to exclude women from certain jobs or to enforce women's role as wives and mothers. The "male breadwinner" model is still imbedded in most policies in northern welfare states (McPhail 2003; Pascall 1997). At the same time, policies are a result of agency and intensive lobbying of trade unions, labor and women's movements - the same applies to the development policies, which are deeply influenced by transnational feminist movements and "governance feminism" (Halley et al. 2006; cf. Lovenduski 2005).

${ }^{3}$ The means of gender equality to the end of economic growth was recently emphasised by McKinsey\&Company in the study "The Power of Parity: How Advancing Women's Equality Can Add \$12 Trillion to Global Growth” (McKinsey Global Institute 2015). 
I will now turn to the Marxist concept of primitive accumulation and new enclosures as a theoretical perspective which can help to understand the way social reproduction is addressed in the SDGs and other global policies, as well as its effects and policy implications for social, economic and gender inequalities.

\section{Feminist Perspectives on Primitive Accumulation and New Enclosures}

The concept of primitive accumulation is currently having a revival in academic scholarship across disciplines. It is used to explain a wide range of phenomena and problems of our time, including land grabs in the Global South (Hall 2013), the debt economy (e.g Sassen 2010), the emergence of a new imperialism through "accumulation by dispossession" (Harvey 2004), the appropriation of nature (e.g. Moore 2017), time (e.g. Brown 2009), life and knowledge (e.g. De Angelis 2001) or web 2.0-communication (e.g. Ekman 2012). Although social and ethnic inequalities, such as the constitution and reproduction of difference as another effect of primitive accumulation (Walker 2011), are widely debated, gender relations are systematically left out (apart from a few exceptions in feminist scholarship, which I will turn to later). I argue that an intersectional lens, which includes race, class, gender as structural categories and main drivers of the reproduction of inequalities (e.g. Crenshaw 1991; Davis 2008; Yuval-Davis 2006), enhances our understanding of new forms of enclosures, since the appropriation-process builds on already existing inequalities and incorporates them to make them more compatible with the logic of capital accumulation (De Angelis 2001).

The concept of 'primitive accumulation'4 was introduced by Marx (1990/1867, 873$940)$ to describe the 'original sin' or the prerequisite for capital accumulation. Marx referred to primitive accumulation as the division of the masses from their means of production, which includes two processes central to the emergence of capitalism. First and foremost, the creation of a "free" and "unattached" labour force which was forced to sell its labour power and second, the transformation of land and other means of production into capital. Revisiting Marx description of primitive accumulation from a feminist perspective raises another thought-provoking aspect: the fact that Marx reflects the redefinition of primitive accumulation as a process of emancipation (from serfdom) by bourgeois historians can be linked to the integration of women into the labour force, which is interpreted as their emancipation by most dominant forms of feminism (Farris 2017). The dialectic relation between extra-economic domination and economic exploitation is what makes the concept of 'primitive accumulation' so intriguing for feminist theory, especially in order to understand reproductive work in a globalised economy.

Marx describes primitive accumulation as a historical process and a one-time and concluded event, which was criticised and refined by Rosa Luxemburg (2003/1913), who theorised colonialism and the dissemination of colonial rule as an absolute precondition for capital accumulation: "Only the continuous and progressive disintegration of non-capitalist organisations makes accumulation of capital possible" (Luxemburg 2003/1913, 397). Before the concept gained more prominence in the 1990s under the name of 'new enclosures' (e.g. Midnight Notes Collective 1990), the feminist scholars Maria Mies, Veronika Bennholdt-Thomson and Claudia von Werlhof

${ }^{4}$ The term 'primitive accumulation' as a translation for "ursprüngliche Akkumulation" is in a sense misleading, since "ursprünglich" literally means primary or original. 'Primitive' should therefore not be understood in an atavistic or barbaric sense. 
has supplemented primitive accumulation to entail not only territorial enclosures, but also extra-economic spheres, namely women's care and housework, as "the last colony" (Mies, Bennholdt-Thomsen and Von Werlhof 1988) and linked its role in capital accumulation to subsistence farming in the Global South. Gender relations are therefore not a random principle, but constitutive for capitalist accumulation: "capitalism has to use, to strengthen, or even to invent, patriarchal men-women relations if it wants to maintain its accumulation model" (Mies 2014, 170).

The 'Bielefeld approach'5 theoretically enriched the concept of primitive accumulation by showing that processes of enclosure are still constitutive for current capitalist accumulation (Soiland 2016). The fact that capitalism itself relies on these spheres and, therefore, has an interest in maintaining them (temporarily) outside of capital accumulation, while profiting from the cheaper social reproductive costs of labour, added another analytical aspect to the concept of primitive accumulation, which later on was described as 'temporal fix' (Harvey 2001; Jessop 2006). Another relevant aspect in the work of Maria Mies was the concept of Hausfrauisierung (housewifisation) as paradigmatic for the connection between unpaid and paid work. It describes the spread of precarious, part-time and undervalued jobs and the devaluation of work (Mies 1982), which became one of the main characteristics of labour in the era of globalisation. These theoretical contributions have been widely ignored by newer reflections on enclosures, which at the same time neglect the gender dimension of enclosures to a large extend (Soiland 2016).

Feminist scholars have used the concept of enclosures to explain how unpaid care and housework is commodified or de-commodified in order to integrate women into the labour force or to reduce the costs of social reproduction according to the needs of the economy (e.g. Bakker 2007; Feministische Autorinnengruppe 2013; Hartsock 2006; LeBaron 2010; Mies 2014; Soiland 2016). Silvia Federici (2012b) accordingly calls women the "shock absorber" of neoliberal globalisation. In the book 'Caliban and the Witch' she supplements the concept of primitive accumulation with "an accumulation of differences and divisions within the working class, whereby hierarchies built upon gender, as well as "race" and age, become constitutive of class rule and the formation of the modern proletariat" (Federici 2004, 63). Existent intersecting inequalities are thus appropriated and exacerbated during the process of enclosure (cf. Walker 2011).

Notwithstanding the importance of the theoretical contributions of the Bielefeld scholars and Silvia Federici, I would contest their romanticised view of the common as associated with nature and managed in a collective way. This conceptualisation of primitive accumulation as violent in contrast to a peaceful and collective common prevents a deeper understanding of the enclosure process and the reasons for its success (cf. Mezzadra 2011). State regulations and policies establish new enclosures in times of capital accumulation's crises (Harvey 2004), because the continuous reproduction of the capitalist modes of production and the social reproduction of the labour force has to be ensured by the state (Althusser 2014; cf. Mclntosh 1978; Fraser 2016). Although enclosures can be violent in their effects, governance or governmentality, to use Foucault's term, is legitimised by targeting the alleged wellbeing of the population (Foucault 2008). The process of enclosure is thereby complex, rather subtle and has contradictory effects, which enable certain aspects of freedom or emancipation and at the same time produce and reproduce inequalities, which I will

${ }^{5}$ A name Maria Mies has opposed due to of the lack of institutional support by the University of Bielefeld (Mies 2001). 
show in the following chapter. It is important to keep in mind these ambivalences, as they create opportunities for the contestation of enclosures.

\section{The Example of the Sustainable Development Goals and the Double Form of Enclosure of Social Reproduction}

"[...] the emergence of feminism and the category of the 'independent woman' in the west is related to colonial expansion and the re-construction of an 'other' woman 'elsewhere'." (Rosemary Hennessy 1990, 261)

I will use the example of the Sustainable Development Goals by the United Nations to illustrate how social policies addressing social reproduction can be understood as a double form of enclosure. By aiming to integrate women into the paid workforce, reproductive activities are devalued and thereby create the precondition for their commodification. The first form of enclosure concerns women's further integration into the paid workforce while the second bears on the commodification of care and domestic tasks. Both forms are based on the appropriation of feminist claims about the recognition of housework and of feminist scholarship, which has theorised and operationalised the measurement of social reproductive work (e.g. Antonopoulos and Hirway 2010; World Bank, Blackden and Wodon 2006; Connelly and Kongar 2017; Esquivel et al. 2008). The quantification of reproductive work by feminist political economists has shown its economic relevance in (inter)national accounts, where the Gross Domestic Product and other economic measurements have failed (e.g. Madörin 2011). Whereas feminist scholars have consequently argued for transfer payments and redistribution measures, the same numbers are used by neoliberal think tanks and institutions to emphasise the unused economic potential of unpaid care work (e.g. McKinsey Global Institute 2015).

I do not want to deny that paid work has emancipatory effects for women and enables more leeway for freedom. However, I argue that the respective policies and their implications for gender, social and ethnic inequalities have contradictory effects and are one drastic example of the appropriation of feminist theory and praxis. I will concentrate on the aspects that illustrate the double form of enclosure of women's unpaid work through SDGs as well as problematic rationalities and probable effects.

\subsection{The Enclosure of Social Reproduction through Women's Economic Empowerment}

The implementation praxis of SDG 5.4 has yet to be seen and evaluated, but different policy papers and initiatives already indicate priorities and probable tendencies. One prominent example is the Public-Private-Partnership "UN High-Level Panel on Women's Economic Empowerment", which includes representatives of the UN, businesses and NGOs. The Panel identified different drivers to accelerate women's economic empowerment, among them: "Recognizing, reducing and redistributing unpaid work and care" (UN 2017a), which refers to the '3R-framework for policy response' by Diane Elson (2008), which was publicly represented by the Women's Budget Group in Great Britain (UNPD, Fälth and Blackden 2009). Framing the goal to recognise and value care and domestic work as a means to integrating women into the paid global workforce can also be found in other policy papers, for instance by the Commission on the Status of Women (CSW 2017) or UNDP (2016b). In a recent study about employment strategies for migrant women in Europe, Sara Farris (2017) has shown how the neoliberal notion of women's emancipation through their economic participation is extremely problematic and ambivalent. The policies and programmes 
stigmatise other practises and cultures as backward since empowerment seems to be inseparably linked to economic factors. At the same time, economic inclusion leads to the exploitation of migrant women in low or unpaid precarious jobs in the care sector to mitigate the crisis of social reproduction in the Global North. ${ }^{6}$

The Eurocentric notion of women's empowerment through their participation in paid jobs applies both to the context of development and international cooperation (Chant and Sweetman 2012; Rankin 2001) and to the way social reproduction in the Global South is addressed by international organisations and NGOs. Despite regional differences in the gendered distribution of care and domestic tasks, it is important to note that the 'gender care gap' is significant everywhere and that, on average, women spend between four to five hours a day on this work in almost all regions of the world (OECD et al. 2014).

However, policy papers mainly address the reduction of social reproductive tasks in the Global South by emphasising the relatively low level of infrastructure and its effects on time spent on household activities such as fetching water, firewood and other daily goods. Hence one main strategy to integrate women in the paid workforce is to reduce the burden of unpaid work by investing in infrastructure and technology in developing countries (e.g. World Bank, Blackden and Wodon 2006; CSW 2017; OECD et al. 2014; Razavi 2007; Roberts 2008). ${ }^{7}$ The problem from a materialist feminist perspective is twofold: First, the underlying notion that social reproductive work has no value in itself and should therefore be reduced. This reduction contradicts the goal of recognition if it is achieved through efficiency increases instead of redistributive measures. Second, the modernisation theory rationale, which builds on technology and infrastructure as a universal panacea and thereby legitimises the further privatisation in the Global South (Banerjee-Guha 2013). ${ }^{8}$ The second point is imperative for the enclosure of subsistence farmland as means of production.

Nancy Fraser (2012) and others have shown that the integration of women into the global workforce is a neoliberal strategy, which is deeply linked to the crisis of capitalism and the need for women as a cheap and dispensable workforce. Although these observations describe the transition from a Fordist breadwinner model to a PostFordist adult worker model, the economic "empowerment" of women in the Global South will much likely have similar effects and lead to neo-colonial dependencies as well as new and entrenched inequalities. The SDGs can therefore be understood as an instrument to enclose and devalue women's reproductive work.

\subsection{Enclosure through the Commodification of Social Reproduction}

The other form of enclosure through the formal recognition and valuation of social reproduction lies in the implications and effects for the further commodification of care and domestic tasks. The respective indicator of goal 5.4 measures the "proportion of time spent on unpaid domestic and care work, by sex, age and location" (UN 2017c).

${ }^{6}$ Her study focuses on migrant women in the Netherlands, France and Italy, but her critique can be easily transferred to development projects in the Global South, which follow a similar agenda.

7 Studies have shown that an improved infrastructure can reduce women's time spent for household chores, but the gendered division of unpaid domestic and care work is unlikely to change (ADB 2015).

8 The critique of the modernisation theory rationale is widely debated in post-development theory (e.g. Ziai 2007). 
States have to report their progress made on the SDGs ${ }^{9}$ and are even ranked by private initiatives, like the 'SDG Index and Dashboard' by the Bertelsmann foundation and the Sustainable Development Solutions Network (SDSN) Secretariat (2017). This global benchmarking technique is part of a tendency of evidence-based policy-making in global governance on the basis of statistics, rankings and accountability measures (Lepenies 2015; Norris 2014). Benchmarking is critically reflected in global governmentality literature because it transports the neoliberal notions of competition and self-conduct (Larner and Le Heron 2004), which shift the responsibility for the remedy of policy problems to developing countries (Clegg 2015). Indicators depoliticise social problems and make them appear as objective, scientific knowledge for evidence-based policy-making (Merry 2016).

The indicator of goal 5.4 does not measure the provision of social services, which will likely result in the ascription of women's higher contribution to social reproduction to 'traditions' or 'cultural' causes. In this way, global social policies are emblematic in their construction of "third world women" (Mohanty 1984) (and men) as less emancipated and backward. Kate Bedford (2009) has examined how the World Bank tries to tackle gender stereotypes by aiming to increase men's caring responsibilities and has also shown how the respective programmes were stigmatising mostly poor and rural men as lazy and irresponsible. The programmes were thereby enforcing a neoliberal and heteronormative two-partner sharing model (Ibid.).

Women's disproportionate share of reproductive activities is indeed explained with 'traditional' or 'cultural' norms and gender roles by various policies and policy papers (CSW 2017; UNDP 2016a). Feminist historians have linked the devaluation of social reproduction to the historical division of productive and reproductive work in the advent of capitalism (Bock and Duden 1976); the term 'traditional' is therefore misleading. Gender inequalities in countries of the Global South cannot be separated from colonialism and its implementation of a sexual division of labour and the construction and enforcement of gender inequalities (Federici 2011; 2005). The practice of employing female domestic workers from poorer and mostly rural families also has its roots in colonial rule (Meyiwa 2012).

Since many countries in the Global South have been severely hit by austerity politics and structural adjustment programmes under IWF and World Bank (Rai 2004), their capacities for social infrastructure are deeply limited. Other proposed ways to achieve SDG 5.4 include the reduction of unpaid care, domestic and subsistence work through infrastructure and technology, as I have shown above. The reduction (and redistribution to some extend) also includes the further commodification of unpaid care work by transforming the tasks into precarious, insecure and low paid jobs. This is insofar astonishing as the phenomenon of 'global care chains' and the rising inequality between women on a global level is widely debated in feminist literature on social reproduction (Ehrenreich and Hochschild 2002; Hochschild 2000). 'Global care chains' describe the feminisation of migration due to the growing demand for care workers in the industrialised countries of the Global North (lbid.). In contrast to the dimension of this phenomenon, which concerns 53 million domestic workers worldwide, of which $83 \%$ are female, this aspect is not addressed by most policies in relation to the

${ }^{9}$ The reporting process focuses only on national states and therefore omits the role of transnational companies and institutions such as the International Monetary Fund in shaping and influencing global power structures. Since no government is legally bound to implement the goals, major policy changes seem very unlikely and are furthermore dependent on the lobbying and pressure of civil society and women's rights organisations (Esquivel 2016). 
recognition of care work (ILO 2013). ${ }^{10}$ The opposite is the case: By not measuring the paid share of care and domestic work in households, and not disaggregating the data acquired about the time spent on paid domestic and care activities by race or ethnicity, the shift from unpaid to undervalued and precariously paid domestic work is not even recognised. To phrase it bluntly: The global commodification of care and its implicit delegation to migrants and other women who are economically forced to take those jobs is not only obscured but even desired and structurally inscribed in the implementation framework of the SDGs. The commodification and delegation of care and domestic work improves the numbers and shows ostensible success on the global benchmarking systems. The 'crisis of social reproduction' in the Global North is, as a result, addressed in the context of global governance by transforming social reproductive work into (low) paid work and thereby further entrenching inequalities between women along the categories of class and race.

Feminist scholars are questioning whether the solution of the crisis of social reproduction is even possible in capitalism (e.g. Fraser 2016). Since the economic logic of social reproduction is so divergent from other economic sectors (Baumol 2012), the state has to intervene to secure the continuous reproduction of the work force. In the case of the SDGs these state interventions or enclosures are built on a global system of ethnic, social and gender inequalities between and within countries in the context of neo-colonial dependencies (Dossa 2007; Sanyal 2014). The effects will in consequence compound and not tackle those inequalities.

It is therefore important both to ask the heretical question how feminist networks and scholars contribute to those enclosures and, more broadly, to try to shed some light on the politics of appropriation, hopefully inciting some reflections about possible feminist counter strategies and interventions.

\section{The Quandary of Appropriation and Possible Counter Strategies}

The contributions of a transnational feminism including feminist movements, networks and scholars have had a major influence on the integration of gender aspects in global and national policies, Gender Mainstreaming being the best-known example (e.g. Caglar 2013; Friedman 2003). The case of the enclosure of social reproduction through the SDGs shows how ambivalent this final success story can turn out, because its valuation seems to be vaporized and reversed. Frequently, the discourse on the appropriation of feminism (e.g. Fraser 2012) nostalgically idealises earlier forms of feminisms or somehow implies the purity of a 'true' feminism, which neglects the fact that feminism has in its hegemonial and predominant form always been liberal or neoliberal (Farris 2017). The search for the culprit, feminism or the state, is in itself misleading, because feminism has long been institutionalised and incorporated in governmental administration and policies (Halley et al. 2006; Lovenduski 2005). Feminist scholarship has accordingly reflected whether the state is the right addressee for emancipatory politics (Longwe 1997) or if it is at all possible to "dismantle the master's house, with the master's tools" (Lorde 1983). Nevertheless, the state, or in this case global governance institutions, are explicitly or implicitly addressed by most feminist actors and scholars to solve or at least mitigate the contradiction between capitalism and social reproduction (e.g. Elson 2016; Fraser 2016; Visel 2013; Williams 2010).

${ }^{10}$ The International Labour Organization (ILO) being one exception (Visel 2013). 
The question what kind of political interventions are less prone to appropriation remains. In the case of social reproduction, Marxist feminists also addressed the state by claiming 'wages for housework' and thereby highlighted the importance of unpaid household chores for capital accumulation (Cox and Federici 1975; Dalla Costa and James 1972). Revisiting their statements retrieves the contradictions between emancipatory aspects of women's economic empowerment and its enclosures, but also opens up perspectives beyond the regulation of the state: "It is one thing to organise communally the way we want to eat (by ourselves, in groups, etc.) and then ask the State to pay for it, and it is the opposite thing to ask the State to organise our meals. In one case we regain some control over our lives, in the other we extend the State's control over us" (Federici 1975, 7). This example illustrates how feminist movements need spaces to organise outside international governmental frames which have determined the transnational women's movement for centuries (see Caglar, Prügl and Zwingel 2013). Otherwise the SDGs and other social policies have the chance to undermine, de-radicalise and silence political struggles on the basis of rhetorical appropriations (cf. Weber 2017). Taking the concept of enclosure seriously means that it can be contested, re-appropriated and reversed (De Angelis 2001). The valuation and re-appropriation of social reproduction does not only concern everyone, but transforms everyone's life.

\section{References}

ADB. 2015. Balancing the Burden? Desk Review of Women's Time Poverty and Infrastructure in Asia and the Pacific. Manila: Asian Development Bank.

Althusser, Louis. 2014. On the Reproduction of Capitalism: Ideology and Ideological State Apparatuses. London: Verso Books.

Antonopoulos, Rania. 2009. The Unpaid Care Work-Paid Work Connection. Working Paper 86. Geneva: ILO.

Antonopoulos, Rania, and Indira Hirway, eds. 2010. Unpaid Work and the Economy: Gender, Time Use and Poverty in Developing Countries. New York: Palgrace Macmillan.

Bakker, Isabella. 2007. Social Reproduction and the Constitution of a Gendered Political Economy. New Political Economy 12 (4): 541-556.

Bakker, Isabella and Stephen Gill. 2003. Global Political Economy and Social Reproduction. In Power, Production and Social Reproduction: Human in/Security in the Global Political Economy, edited by Isabella Bakker and Stephen Gill, 3-16. New York: Palgrave Macmillan.

Banerjee-Guha, Swapna. 2013. Accumulation and Dispossession: Contradictions of Growth and Development in Contemporary India. South Asia: Journal of South Asian Studies 36 (2): 165-179.

Baumol, William J. 2012. The Cost Disease: Why Computers Get Cheaper and Health Care Doesn't. New Haven: Yale University Press.

Bedford, Kate. 2009. Developing Partnerships: Gender, Sexuality, and the Reformed World Bank. Minneapolis: University of Minnesota Press.

Bennholdt-Thomsen, Veronika and Maria Mies. 2000. Subsistence Perspective: Beyond the Globalised Economy. London: Zed Books.

Bertelsmann Stiftung and SDSN Secretariat. 2017. Sdg Index \& Dashboards. Accessed January 30, 2018. http://www.sdgindex.org/

Bibler, Sarah and Elaine Zuckerman. 2013. The Care Connection: The World Bank and Women's Unpaid Care Work in Select Sub-Saharan African Countries. WIDER Working Paper 131. New York: United Nations University.

Bock, Gisela and Barbara Duden. 1976. Arbeit aus Liebe-Liebe als Arbeit. Zur Entstehung der Hausarbeit im Kapitalismus. In Frauen und Wissenschaft. Beiträge zur Berliner 
Sommeruniversität für Frauen, edited by Gruppe Berliner Dozentinnen, 118-199. Berlin: Courage-Verlag.

Brown, Tony C. 2009. The Time of Globalization: Rethinking Primitive Accumulation. Rethinking Marxism 21 (4): 571-584.

Caglar, Gülay. 2013. Gender Mainstreaming. Politics \& Gender 9 (3): 336-344.

Caglar, Gülay, Elisabeth Prügl and Susanne Zwingel, eds. 2013. Feminist Strategies in International Governance. Vol. 70, Routledge Global Institutions Series. New York: Routledge.

Chant, Sylvia and Caroline Sweetman. 2012. Fixing Women or Fixing the World? 'Smart Economics', Efficiency Approaches, and Gender Equality in Development. Gender \& Development 20 (3): 517-529.

Clegg, Liam. 2015. Benchmarking and Blame Games: Exploring the Contestation of the Millennium Development Goals. Review of International Studies 41 (5): 947-967.

Connelly, Rachel and Ebru Kongar, eds. 2017. Gender and Time Use in a Global Context: The Economics of Employment and Unpaid Labor. New York: Palgrave Macmillan.

Cox, Nicole and Silvia Federici. 1975. Counter-Planning from the Kitchen: Wages for Housework, a Perspective on Capital and the Left. New York: New York Wages for Housework Committee and Falling Wall Press.

Crenshaw, Kimberle. 1991. Mapping the Margins: Intersectionality, Identity Politics, and Violence against Women of Color. Stanford Law Review 43 (6): 1241-1299.

CSW. 2017. Commission on the Status of Women. Report on the Sixty-First Session (24 March 2016 and 13-24 March 2017). Economic and Social Council Official Records. New York: United Nations.

Dalla Costa, Mariarosa and Selma James. 1972. The Power of Women and the Subversion of the Community. Bristol: Falling Wall Press.

Davis, Kathy. 2008. Intersectionality as Buzzword: A Sociology of Science Perspective on What Makes a Feminist Theory Successful. Feminist Theory 9 (1): 67-85.

De Angelis, Massimo. 2001. Marx and Primitive Accumulation: The Continuous Character of Capital's Enclosures. The Commoner (2): 1-22. Accessed January 30, 2018. http://www.commoner.org.uk/02deangelis.pdf

Donath, Susan. 2000. The Other Economy: A Suggestion for a Distinctively Feminist Economics. Feminist Economics 6 (1): 115-123.

Dossa, Shiraz. 2007. Slicing up 'Development': Colonialism, Political Theory, Ethics. Third World Quarterly 28 (5): 887-899.

Ehrenreich, Barbara and Arlie Russell Hochschild. 2002. Global Woman: Nannies, Maids, and Sex Workers in the New Economy. New York: Henry Holt and Company.

Ekman, Mattias. 2012. Understanding Accumulation: The Relevance of Marx's Theory of Primitive Accumulation in Media and Communication Studies. tripleC: Communication, Capitalism \& Critique. Open Access Journal for a Global Sustainable Information Society 10 (2): 156-170. Accessed January 29, 2018. http://triplec.at/index.php/tripleC/article/view/407

Elson, Diane. 2016. Plan F: Feminist Plan for a Caring and Sustainable Economy. Globalizations 13 (6): 919-921.

Elson, Diane. 2008. The Three R's of Unpaid Work: Recognition, Reduction and Redistribution. Presented at the Expert Group Meeting on Unpaid Work, Economic Development and Human Well-Being, United Nations Development Programme, New York.

Elson, Diane. 1998. The Economic, the Political and the Domestic: Businesses, States and Households in the Organisation of Production. New Political Economy 3 (2): 189-208.

Esquivel, Valeria. 2016. Power and the Sustainable Development Goals: A Feminist Analysis. Gender \& Development 24 (1): 9-23.

Esquivel, Valeria, Debbie Budlender, Nancy Folbre, and Indira Hirway. 2008. Explorations: Time-Use Surveys in the South. Feminist Economics 14 (3): 107-152. 
EU. 2016. Report on Equality between Women and Men 2015. Committee on Women's Rights and Gender Equality. Brussels: European Union.

European Parliament, Committee on Women's Rights and Gender Equality. 2017. Report on Equality between Women and Men in the European Union in 2014-2015. Plenary Sitting. Brussels: European Parliament.

Farris, Sara R. 2017. In the Name of Women's Rights: The Rise of Femonationalism. Durham: Duke University Press.

Federici, Silvia. 2014. The Reproduction of Labour Power in the Global Economy and the Unfinished Feminist Revolution. In Workers and Labors in Globalized Capitalism: Contemporary Themes and Theoretical Issues., edited by Maurizio Atzeni, 85-110. New York: Palgrave Macmillan.

Federici, Silvia. 2012a. Revolution at Point Zero: Housework, Reproduction, and Feminist Struggle. Oakland: PM Press.

Federici, Silvia. 2012b. The Unfinished Feminist Revolution. The Commoner 15: 185-197. Accessed January 30, 2018, http://www.commoner.org.uk/wpcontent/uploads/2012/02/08-federici.pdf

Federici, Silvia. 2011. Women, Land Struggles, and the Reconstruction of the Commons. Journal of Labor and Society 14 (1): 41-56.

Federici, Silvia. 2005. Women, Land-Struggles and the Valorization of Labor. The Commoner 10: 216-233. Accessed January 29, 2018. http://www.commoner.org.uk/10federici.pdf

Federici, Silvia. 2004. Caliban and the Witch: Women, the Body and Primitive Accumulation. New York: Autonomedia.

Federici, Silvia. 1975. Wages against Housework. Bristol: Power of Women Collective and Falling Wall Press.

Feministische Autorinnengruppe. 2013. Das Theorem der Neuen Landnahme: Eine Feministische Rückeroberung. In Jahrbuch 2013. Care Statt Crash: Sorgeökonomie und die Überwindung des Kapitalismus, edited by Denknetz, 99-118. Zürich: Edition 8.

Foucault, Michel. 2008. The Birth of Biopolitics: Lectures at the Collège De France, 19781979. Translated by Graham Burchell. Edited by Arnold I Davidson. New York: Palgrave Macmillan.

Fraser, Nancy. 2016. Contradictions of Capital and Care. New Left Review 100: 99-117.

Fraser, Nancy. 2012. Feminism, Capitalism, and the Cunning of History. New Left Review 56: $97-117$.

Friedman, Elisabeth Jay. 2003. Gendering the Agenda: The Impact of the Transnational Women's Rights Movement at the UN Conferences of the 1990s. Women's Studies International Forum 26 (4): 313-331.

Glassman, Jim. 2006. Primitive Accumulation, Accumulation by Dispossession, Accumulation by 'Extra-Economic' Means. Progress in Human Geography 30 (5): 608625.

Hall, Derek. 2013. Primitive Accumulation, Accumulation by Dispossession and the Global Land Grab. Third World Quarterly 34 (9): 1582-1604.

Halley, Janet, Prabha Kotiswaran, Hila Shamir, and Chantal Thomas. 2006. From the International to the Local in Feminist Legal Responses to Rape, Prostitution/Sex Work, and Sex Trafficking: Four Studies in Contemporary Governance Feminism. Harvard Journal of Law \& Gender 29 (2): 335-423.

Hartsock, Nancy. 2006. Globalization and Primitive Accumulation: The Contributions of David Harvey's Dialectical Marxism. In David Harvey: A Critical Reader, edited by Noel Castree and Derek Gregory. Oxford: Blackwell Publishing.Harvey, David. 2004. The "New Imperialism": Accumulation by Dispossession. Socialist Register 40: 63-87.

Harvey, David. 2001. Globalization and the "Spatial Fix". Geographische Revue 3 (2): 23-30.

Hennessy, Rosemary. 1990. Materialist Feminism and Foucault: The Politics of Appropriation. Rethinking Marxism 3 (3-4): 251-274. 
Himmelweit, Susan. 1995. The Discovery of "Unpaid Work": The Social Consequences of the Expansion of "Work". Feminist Economics 1 (2): 1-19.

Hochschild, Arlie Russell. 2000. Global Care Chains and Emotional Surplus Value. In On the Edge: Living with Global Capitalism, edited by Anthony Giddens and Will Hutton, 130-146. London: Random House Books.

ILO. 2013. Domestic Workers across the World: Global and Regional Statistics and the Extent of Legal Protection. Geneva: International Labour Office.

Jessop, Bob. 2006. Spatial Fixes, Temporal Fixes and Spatio-Temporal Fixes. In David Harvey: A Critical Reader, edited by Noel Castree and Derek Gregory, 142-166. Oxford: Blackwell Publishing.

Kabeer, Naila. 2015. Gender Equality, the Mdgs and the Sdgs: Achievements, Lessons and Concerns. International Growth Centre, October 1. https://www.theigc.org/blog/genderequality-the-mdgs-and-the-sdgs-achievements-lessons-and-concerns/

Kabeer, Naila and Luisa Natali. 2013. Gender Equality and Economic Growth: Is There a Win-Win? IDS Working Paper 417. Brighton: Institute for Development Studies.

Larner, Wendy and Richard Le Heron. 2004. Global Benchmarking: Participating 'at a Distance' in the Globalizing Economy. In Global Governmentality: Governing International Spaces, edited by Wendy Larner and William Walters, 212-232. New York: Routledge.

LeBaron, Genevieve. 2010. The Political Economy of the Household: Neoliberal Restructuring, Enclosures, and Daily Life. Review of International Political Economy 17 (5): 889-912.

Lepenies, Philipp. 2015. Modeling, Statistics and Political Circumstances: How the Concept of Economic Development Triumphed and What This Means for Development Alternatives. European Journal of Sociology/Archives Européennes de Sociologie 56 (3): 375-404.

Longwe, Sara Hlupekile. 1997. The Evaporation of Gender Policies in the Patriarchal Cooking Pot. Development in Practice 7 (2): 148-156.

Lorde, Audre. 1983. The Master's Tools Will Never Dismantle the Master's House. In This Bridge Called My Back: Writings by Radical Women of Color, edited by Gloria Anzaldúa and Cherríe Moraga, 94-103. New York: Kitchen Table Press.

Lovenduski, Joni, ed. 2005. State Feminism and Political Representation. Cambridge: Cambridge University Press.

Luxemburg, Rosa. 2003/1913. The Accumulation of Capital. New York: Routledge.

Madörin, Mascha. 2011. Das Auseinanderdriften der Arbeitsproduktivitäten: Eine Feministische Sicht. In Jahrbuch 2011: Gesellschaftliche Produktivität Jenseits der Warenform, edited by Denknetz, 56-70. Zürich: Edition 8.

Marx, Karl. 1990/1867. Capital: A Critique of Political Economy: Volume One. London: Penguin.

McIntosh, Mary. 1978. The State and the Oppression of Women. In Feminism and Materialism, edited by Annette Kuhn and Ann-Marie Wolpe. London: Routledge.

McKinsey Global Institute. 2015. The Power of Parity: How Advancing Women's Equality Can Add \$12 Trillion to Global Growth. London, San Francisco, Shanghai: McKinsey\&Company.

McPhail, Beverly A. 2003. A Feminist Policy Analysis Framework: Through a Gendered Lens. The Social Policy Journal 2 (2-3): 39-61.

Merry, Sally Engle. 2016. The Seductions of Quantification: Measuring Human Rights, Gender Violence, and Sex Trafficking. Chicago, IL: University of Chicago Press.

Meyiwa, Thenjiwe. 2012. Domestic Workers' Rights in Global Development Indicators. Agenda 26 (1): 54-66.

Mezzadra, Sandro. 2011. The Topicality of Prehistory: A New Reading of Marx's Analysis of "So-Called Primitive Accumulation". Rethinking Marxism 23 (3): 302-321.

Midnight Notes Collective. 1990. Introduction to the New Enclosures. Midnight Notes 10: 1-9. Accessed January 29, 2018. http://www.midnightnotes.org/pdfnewenc1.pdf 
Mies, Maria. 2014. Patriarchy and Accumulation on a World Scale: Women in the International Division of Labour. London: Zed Books.

Mies, Maria. 2001. Hausfrauisierung, Globalisierung, Subsistenzperspektive. In Soziale Verortung der Geschlechter: Gesellschaftstheorie und Feministische Kritik, edited by Gudrun-Axeli Knapp and Angelika Wetterer, 157-187. Münster: Westfälisches Dampfboot.

Mies, Maria. 1986. Patriarchy and Accumulation on a World Scale: Women in the International Division of Labor. London: Zed Books.

Mies, Maria. 1982. The Lace Makers of Narsapur: Indian Housewives Produce for the World Market. London: Zed Press.

Mies, Maria, Veronika Bennholdt-Thomsen and Claudia Von Werlhof. 1988. Women: The Last Colony. London: Zed Books.

Mohanty, Chandra Talpade. 1984. Under Western Eyes: Feminist Scholarship and Colonial Discourses. Feminist Review 30: 61-88.

Moore, Jason W. 2017. The Capitalocene Part II: Accumulation by Appropriation and the Centrality of Unpaid Work/Energy. The Journal of Peasant Studies 45 (2): 237-279.

Norris, Jesse J. 2014. Rethinking Accountability in New Governance. Innovation: The European Journal of Social Science Research 27 (3): 199-219.

OEC and Federico Cingano. 2014. Trends in Income Inequality and Its Impact on Economic Growth. OECD Social, Employment and Migration Working Paper 163. Paris: OECD.

OECD, Gaëlle Ferrant, Luca Maria Pesando and Keiko Nowacka. 2014. Unpaid Care Work: The Missing Link in the Analysis of Gender Gaps in Labour Outcomes. Policy Brief. Paris: OECD.

Ostry, Jonathan D., Andrew Berg and Charalambos G. Tsangarides. 2014. Redistribution, Inequality, and Growth. Staff Discussion Note. Washington, DC: International Monetary Fund.

Pascall, Gillian. 1997. Social Policy: A New Feminist Analysis. London: Routledge.

Rai, Shirin. 2004. Gendering Global Governance. International Feminist Journal of Politics 6 (4): 579-601.

Rai, Shirin M, Catherine Hoskyns and Dania Thomas. 2014. Depletion: The Cost of Social Reproduction. International Feminist Journal of Politics 16 (1): 86-105.

Rankin, Katharine N. 2001. Governing Development: Neoliberalism, Microcredit, and Rational Economic Woman. Economy and Society 30 (1): 18-37.

Razavi, Shahra. 2016. The 2030 Agenda: Challenges of Implementation to Attain Gender Equality and Women's Rights. Gender \& Development 24 (1): 25-41.

Razavi, Shahra. 2007. The Political and Social Economy of Care in a Development Context: Conceptual Issues, Research Questions and Policy Options. Gender and Development Programme Paper 3. Geneva: United Nations Research Institute for Social Development.

Roberts, Adrienne. 2008. Privatizing Social Reproduction: The Primitive Accumulation of Water in an Era of Neoliberalism. Antipode 40 (4): 535-560.

Sanyal, Kalyan. 2014. Rethinking Capitalist Development: Primitive Accumulation, Governmentality and Post-Colonial Capitalism. New Delhi: Routledge.

Sassen, Saskia. 2010. A Savage Sorting of Winners and Losers: Contemporary Versions of Primitive Accumulation. Globalizations 7 (1-2): 23-50.

Soiland, Tove. 2016. A Feminist Approach to Primitive Accumulation. In Rosa Luxemburg: A Permanent Challenge for Political Economy, edited by Judith Dellheim and Frieder Otto Wolf, 185-217. London: Palgrave Macmillan.

Stevens, Casey and Norichika Kanie. 2016. The Transformative Potential of the Sustainable Development Goals (Sdgs). International Environmental Agreements: Politics, Law and Economics 16 (3): 393-396.

Stuart, Elizabeth and Jessica Woodroffe. 2016. Leaving No-One Behind: Can the Sustainable Development Goals Succeed Where the Millennium Development Goals Lacked? Gender \& Development 24 (1): 69-81. 
UN. 2015. Resolution A/Res/70/1. Transforming Our World: The 2030 Agenda for Sustainable Development. Resolution adopted by the General Assembly on 25 September 2015. New York: United Nations.

UN. 2017a. Leave No One Behind. Taking Action for Transformational Change on Women's Economic Empowerment. Report of The UN Secretary-General's, High-Level Panel on Women's Economic Empowerment. New York: United Nations.

UN. 2017b. Progress Towards the Sustainable Development Goals: Report of the Secretary General 2017 Session: High Level Political Forum on Sustainable Development. New York: United Nations Economic and Social Council.

UN. 2017c. Resolution A/Res/71/313: Work of the Statistical Commission Pertaining to the 2030 Agenda for Sustainable Development. Resolution adopted by the General Assembly on 6 July 2017. New York: United Nations.

UNDP. 2016a. Human Development Report 2016: Human Development for Everyone. New York: United Nations Development Programme.

UNDP. 2016b. UNDP Support to the Implementation of the Sustainable Development Goals. United Nations Development Programme, Accessed January 30, 2018. http://www.undp.org/content/undp/en/home/librarypage/sustainable-developmentgoals/undp-support-to-the-implementation-of-the-2030-agenda/

UNPD, Anna Fälth and Mark Blackden. 2009. Unpaid Care Work. UNDP Policy Brief: Gender Equality and Poverty Reduction. New York: United Nations Development Programme.

Visel, Stefanie. 2013. Who Cares? - The ILO Convention 'Decent Work for Domestic Workers'. Transnational Social Review 3 (2): 229-243.

Walker, Gavin. 2011. Primitive Accumulation and the Formation of Difference: On Marx and Schmitt. Rethinking Marxism 23 (3): 384-404.

Weber, Heloise. 2017. Politics of 'Leaving No One Behind': Contesting the 2030 Sustainable Development Goals Agenda. Globalizations 14 (3): 399-414.

Williams, Fiona. 2010. Claiming and Framing in the Making of Care Policies: The Recognition and Redistribution of Care. Gender and Development Programme Paper 13. November: United Nations Research Institute for Social Development.

Winker, Gabriele. 2015. Care Revolution. Bielefeld: Transcript Verlag.

World Bank, C Mark Blackden and Quentin Wodon. 2006. Gender, Time Use, and Poverty in Sub-Saharan Africa. World Bank Working Paper 73. Washington: World Bank Publications.

Yuval-Davis, Nira. 2006. Intersectionality and Feminist Politics. European Journal of Women's Studies 13 (3): 193-209.

Ziai, Aram, ed. 2007. Exploring Post-Development: Theory and Practice, Problems and Perspectives. Oxon: Routledge.

\section{About the Author}

\section{Friederike Beier}

Friederike Beier is a political scientist, feminist activist and research associate at the Centre for Gender and Diversity at the Otto-Suhr-Institute for Political Science/Freie Universität Berlin. Her PhD research is about "Governing Time and Gender. The Recognition and Measurement of Social Reproduction in Global Governance", wherein she uses feminist materialist state theory to examine the appropriation of Social Reproduction through the 'Politics of Numbers'. Her further research interests are Feminist Political Economy, Materialist State Theory and Global Governmentality Studies. In her former professional career, she was a women's representative at the Alice Salomon University Berlin and a senior public servant for the Berlin Senate. 